\title{
Coastal fish assemblages and predation pressure in northern- central Chilean Lessonia trabeculata kelp forests and barren grounds
}

\author{
Nicolás Riquelme-Pérez ${ }^{1}$, Catalina A Musrri ${ }^{1}$, Wolfgang B Stotz ${ }^{1}$, Osvaldo Cerda ${ }^{1}$, Oscar Pino-Olivares ${ }^{1}$, Martin \\ Thiel ${ }^{\text {Corresp. 1, 2,3 }}$ \\ ${ }^{1}$ Facultad de Ciencias del Mar, Universidad Católica del Norte, Coquimbo, Chile \\ 2 Millennium Nucleus Ecology and Sustainable Management of Oceanic Island (ESMOI), Coquimbo, Chile \\ ${ }^{3}$ Centro de Estudios Avanzados en Zonas Áridas (CEAZA), Coquimbo, Chile \\ Corresponding Author: Martin Thiel \\ Email address: thiel@ucn.cl
}

Kelp forests are declining in many parts of the globe, which can lead to the spreading of barren grounds. Increased abundances of grazers, mainly due to reduction of their predators, are among the causes of this development. Here, we compared the species richness (SR), frequency of occurrence (FO) and maximum abundance (MaxN) of predatory fish and, their predation pressure between kelp forest and barren ground habitats of northern-central Chile. Sampling was done using baited underwater cameras with vertical and horizontal orientation. Two prey organisms were used as tethered baits, the black sea urchin Tetrapygus niger and the porcelanid crab Petrolisthes laevigatus. SR did not show major differences between habitats, while FO and MaxN were higher on barren grounds in vertical videos, with no major differences between habitats in horizontal videos. Predation pressure did not differ between habitats, but after $24 \mathrm{~h}$ consumption of porcelanid crabs was significantly higher than that of sea urchins. Scartichthys viridis/gigas was the main predator, accounting for $82 \%$ of the observed predation events on $P$. laevigatus. Most of these attacks occurred on barren grounds. Scartichthys viridis/gigas was the only fish observed attacking (but not consuming) tethered sea urchins. High abundances of opportunistic predators (S. viridis/gigas) are probably related low abundances of large predatory fishes. These results suggest that intense fishing activity on large predators, and their resulting low abundances, could result in low predation pressure on sea urchins, thereby contributing to the increase of $T$. niger abundances in subtidal rocky habitats. 


\section{Coastal fish assemblages and predation pressure in}

\section{2 northern-central Chilean Lessonia trabeculata kelp}

\section{3 forests and barren grounds.}

4

5 Nicolás Riquelme-Pérez ${ }^{1}$, Catalina A. Musrri ${ }^{1}$, Wolfgang B. Stotz ${ }^{1,3}$, Osvaldo Cerda ${ }^{1}$, Oscar

6 Pino-Olivares ${ }^{1} \&$ Martin Thiel $^{1,2,3}$.

7

$8{ }^{1}$ Facultad de Ciencias del Mar, Universidad Católica del Norte, Larrondo 1281, Coquimbo,

9 Chile

$10{ }^{2}$ Millennium Nucleus Ecology and Sustainable Management of Oceanic Island (ESMOI),

11 Coquimbo, Chile.

$12{ }^{3}$ Centro de Estudios Avanzados en Zonas Áridas (CEAZA), Coquimbo, Chile.

14 Corresponding author:

15 Martin Thiel ${ }^{1,2,3}$

16 Street address, Larrondo 1281, Coquimbo, Chile

17 Email address: thiel@ucn.cl 


\section{Abstract}

20 Kelp forests are declining in many parts of the globe, which can lead to the spreading of barren

21 grounds. Increased abundances of grazers, mainly due to reduction of their predators, are among

22 the causes of this development. Here, we compared the species richness (SR), frequency of

23 occurrence (FO) and maximum abundance (MaxN) of predatory fish and, their predation

24 pressure between kelp forest and barren ground habitats of northern-central Chile. Sampling was

25 done using baited underwater cameras with vertical and horizontal orientation. Two prey

organisms were used as tethered baits, the black sea urchin Tetrapygus niger and the porcelanid crab Petrolisthes laevigatus. SR did not show major differences between habitats, while FO and MaxN were higher on barren grounds in vertical videos, with no major differences between habitats in horizontal videos. Predation pressure did not differ between habitats, but after $24 \mathrm{~h}$ consumption of porcelanid crabs was significantly higher than that of sea urchins. Scartichthys viridis/gigas was the main predator, accounting for $82 \%$ of the observed predation events on $P$. laevigatus. Most of these attacks occurred on barren grounds. Scartichthys viridis/gigas was the only fish observed attacking (but not consuming) tethered sea urchins. High abundances of opportunistic predators (S. viridis/gigas) are probably related with low abundances of large predatory fishes. These results suggest that intense fishing activity on large predators, and their resulting low abundances, could result in low predation pressure on sea urchins, thereby contributing to the increase of $T$. niger abundances in subtidal rocky habitats. 


\section{Introduction}

43 Kelp forests are communities formed by large brown seaweeds, which can reach high densities

44 and several meters in height (Wernberg et al., 2019). These ecosystems are vital to a wide diversity of invertebrate and fish species (Steneck et al., 2002; Almanza et al. 2012; Miller et al., 2018), providing them with food, shelter and habitat for larval settlement (Graham et al., 2007;

Teagle et al., 2017). However, global trends indicate a decline in kelp forests (Krumhansl et al., 2016), as a consequence of poor habitat quality, pollution or sedimentation (Foster \& Schiel, 2010), global warming (Wernberg et al., 2010), heatwaves (Wernberg et al., 2013; Oliver et al., 2018), or El Niño events (Tegner \& Dayton, 1987; Vega et al., 2005), which affects the reproduction, settlement and physiology of kelp (Simonson et al., 2015; Hargrave et al., 2017). Kelp abundances also can be affected through direct extraction by humans or by increased abundances of grazers (Tegner \& Dayton, 2000; Steneck et al., 2002). In the absence of these kelp forests, there are often extensive patches of rock devoid of vegetation called "barren grounds", which have low biodiversity and high abundances of grazers, such as sea urchins and snails (Norderhaug \& Christie, 2009; Wernberg et al., 2019).

Grazers, especially sea urchins, are one of the most important factors controlling the distribution of kelp forests and can consume young kelp recruits, thereby suppressing the renewal and recovery of kelp populations (Norderhaug \& Christie, 2009; Konar et al., 2014; Perreault et al., 2014; Wernberg et al., 2019). The increase of grazer populations can be due to natural and/or anthropogenic causes, which might generate favourable conditions for the survival and growth of grazers (Guidetti et al., 2003; Leleu et al., 2012; Konar et al., 2014). The bestdocumented process that affects grazer abundances is the alteration of trophic webs, with a reduced "top-down" pressure due to decreasing predator populations, which then leads to rising 
65

66

67

68

69

grazer populations (Halpern et al., 2006; Leleu et al., 2012; Hamilton \& Caselle, 2015; Medrano et al., 2019). Furthermore, there are several examples of top-down effects in kelp forests, especially in marine reserves or marine protected areas, where predators are protected. In these cases, high predator abundances control grazers leading to increased algal biomass (Guidetti, 2006; Clemente et al., 2010; Leleu et al., 2012; Selden et al., 2017). Outside of protected areas, many of these predators are important marine resources that have been overharvested by humans (Jackson et al., 2001), thus indirectly leading to a higher grazer pressure.

The shallow rocky subtidal zone $(0-20 \mathrm{~m}$ depth $)$ of the Chilean coast is dominated by kelp forests (Lessonia trabeculata and Macrocystis pyrifera) and barren grounds, the latter characterized by high abundances of sea urchins Tetrapygus niger and Loxechinus albus and snails from the genus Tegula (Dayton, 1985; Vásquez \& Buschmann, 1997; Stotz et al., 2016; Pérez-Matus et al., 2017a). In addition to direct human exploitation of seaweeds, these herbivorous species are also considered one of the main causes for the decrease of Chilean kelp forests and their associated fauna (Dayton, 1985; Vásquez \& Santelices, 1990; Vásquez \& Buschmann, 1997; Henríquez et al., 2011; Perreault et al., 2014). This can be due to a decrease in predation pressure on sea urchins. Some fish species, such as Pinguipes chilensis, Semicossyphus darwini, Cheilodactylus variegatus, Oplegnathus insignis and Graus nigra, are important predators in the shallow rocky communities of northern-central Chile (Muñoz \& Ojeda, 1997; Vargas et al., 1999; Pérez-Matus et al., 2012; Pérez-Matus et al., 2017b) where they also prey on these grazer species. However, most of these fishes have been subject to an intense fishing activity with important population declines in northern-central Chile (Godoy et al., 2010), possibly resulting in the high number of sea urchins (Urriago et al., 2012). 
Along the Chilean coast, the effects of sea urchins on kelp have been widely studied (e.g.

88

89

Perreault et al., 2014), but the role of different coastal fish predators in controlling sea urchin populations and the effects of reduced abundances of these fishes in this system are less known. In order to fill this gap, we compared the effect of coastal fishes in kelp forests and on barren grounds in northern-central Chile by surveying fish assemblages and estimating predation on tethered live prey organisms in these contrasting habitats. Kelp forests are structurally complex systems that tend to have greater richness and abundance of predatory species compared to less complex systems (Hauser et al., 2006; Miller et al., 2018; Villegas et al., 2018) such as barren grounds (Sala \& Zabala, 1996; Norderhaug \& Christie, 2009). Therefore, we expected to find higher species richness and abundances of predatory fish in kelp forests than on barren grounds, and hence higher predation pressure on our baits at sites with a greater presence of predators.

\section{Materials \& Methods}

\section{Study location}

The study was conducted at four locations in northern-central Chile $\left(28^{\circ} \mathrm{S}-30^{\circ} \mathrm{S}\right)$ between September 2016 and October 2017 (Table S1; Figure 1). Study locations were Caleta Angosta (CA), Punta Choros (PC), Chungungo (CH), and Guayacancito (GU), which are located within the biogeographic province north of latitude $30^{\circ} \mathrm{S}$, considered as an important biogeographical break (Camus, 2001). These locations were chosen mainly because of the presence of one or both communities of interest (kelp forests and barren grounds) and accessibility to the sites. Kelp forests were mainly composed of Lessonia trabeculata with a minimum extension of $100 \mathrm{~m}$ along the shoreline and had at least a one-year absence of algal harvesting. They were extensive forests with densities that ranged from 0.5 ind. $\mathrm{m}^{2}(\mathrm{PC}$ and $\mathrm{CH})$ to 2 ind. $\mathrm{m}^{2}(\mathrm{CA})$. Barren grounds were composed of open rock fields, including bedrock and boulders. 

exposed to the open sea. Data were collected in different seasons but considering that coastal fishes present in the study area are mainly non-migratory species (Angel \& Ojeda, 2001; PérezMatus et al. 2007) and there are only minor seasonal variations among predatory fish assemblages (Pérez-Matus et al. 2007; Pérez-Matus et al. 2012), findings are comparable over 116 time. grounds were separated by approximately $500 \mathrm{~m}$ at $\mathrm{PC}$ and by $\sim 2,000 \mathrm{~m}$ at $\mathrm{CH}$ (Figure 1). PC and $\mathrm{CH}$ share general characteristics such as (a) distance to large urban centres (moderate potential for anthropogenic disturbances), (b) complex morphology and architecture of the coast and substratum, and (c) administrative regimes under the framework of Management Areas for Benthic Resources (AMERBs for Spanish abbreviation). There were also two distant locations with contrasting habitats, one with a large kelp forest (CA) located at the northern edge of our study area, and the other with an extensive barren ground (GU) located to the south. CA also is located within an AMERB, far from urban centers, while GU is an open access area close to 126 Coquimbo, a major urban center. These locations with non-paired habitat types were included because they belong to coastal stretches of several $\mathrm{km}$ with extensive coverage of the respective habitat type (either kelp forest or barren ground). Along the coast of northern-central Chile, it is difficult to find an ideal kelp forest paired with an adjacent barren ground since some areas are heavily exploited for kelps (within and outside of AMERBs), leading to extensive barren grounds. On the other hand, in other areas kelp forests have remained untouched for many years

132 (mostly due to logistic reasons impeding exploitation) and only small patches without kelps are 133 found. 
135 site", and so we have 3 sites for kelp forest community (KF-CA, KF-PC, KF-CH) and 3 sites for

136 barren ground community (BG-PC, BG-CH, BG-GU).

\section{Experimental design}

139 Fish surveys were conducted with baited remote underwater videos (BRUVs), which allowed us 140 to determine fish abundances, predation pressure and identity of predators. BRUVs consisted of

141 two different types of structures with GoPro cameras in vertical and horizontal orientation,

142 respectively. The first structure (vertical orientation) was a metal frame with the camera fastened

143 in the upper part, which allowed images to be taken from $80 \mathrm{~cm}$ above the bottom (vertical view)

144 of an approximate area of $0.6 \mathrm{~m}^{2}$ (Figure 2A and 2C). The second structure (horizontal

145 orientation) was a plate with a metal arm to which the camera was fastened, which took

146 panoramic images (horizontal view) where the bottom area was measured as a trapezium (Figure

$1472 \mathrm{~B}$ and 2D). Each structure had on its base an eternit fibre cement plate of $40 \times 40 \mathrm{~cm}$ side

148 length, to which prey items were tethered. Each plate contained 6 tethered juveniles of the black

149 sea urchin Tetrapygus niger or 6 juveniles of the porcelanid crab Petrolisthes laevigatus,

150 respectively (see details below). Both types of structures were held on the bottom by concrete

151 pieces of $1 \mathrm{~kg}$ or mesh filled with stones and a small and numbered plastic bottle was attached

152 with a thin rope to each structure, allowing us to rapidly locate them from the boat.

153 Two different types of structures were used due to their respective advantages and/or

154 shortcomings: vertical structures, with a small area, allowed more precise images (because the

155 camera is closer to the plate), which is very useful to identify fish species and to observe

156 predation events on tethered baits when visibility is low (see also Schettini \& Corchs, 2010), but

157 the vertical videos do not allow to observe the surrounding community; on the other hand, 
158 horizontal structures produce a greater, but more imprecise observational area, allowing to see

159 what happens in the surrounding community during the assay period, although high turbidity

160 might occasionally limit visibility. Indeed, most studies that use cameras to describe subtidal fish

161 assemblages have the cameras oriented in the horizontal plane (e.g. Malcolm et al., 2007; Duffy

162 et al., 2015).

163 At each study site (KF-CA, KF-PC, KF-CH, BG-PC, BG-CH, BG-GU), five vertical and

164 five horizontal structures were randomly distributed for each prey (not all of them with camera,

165 because of camera availability). Deployment of the assays was repeated over two different days,

166 because only 5 structures were available of each type (vertical and horizontal; see Table S2). So,

167 after the two deployment days there were 5 replicates with $P$. laevigatus on horizontal structures

168 and 5 replicates with $P$. laevigatus on vertical structures, and the same for $T$. niger. This was

169 done during consecutive days for $\mathrm{CA}$ and $\mathrm{PC}$, but not for $\mathrm{CH}$ and $\mathrm{GU}$, due to logistic reasons

170 (e.g. poor weather conditions delaying the continuation of field work for a few weeks). However,

171 since fish assemblages do not vary much over the year (Pérez-Matus et al., 2007; Pérez-Matus et

172 al., 2012), this should not affect the results. Assays were deployed between 9:00 am and 11:00

173 am, at $\sim 10 \mathrm{~m}$ depth (at sites with abundant kelp coverage in the case of kelp forest habitats, see

174 Figure S1), and separated from each other by similar distances $(\sim 10 \mathrm{~m})$, following a line parallel

175 to the coast. The distance of 10 meters between structures is considered sufficient to prevent the

176 directional movement of fishes from one structure to the next. The fish species observed in our

177 study move randomly and the most frequent fishes are small and territorial species, and thus

178 movements between structures are unlikely and each structure can be considered an independent

179 replicate. Furthermore, visibility in the system is limited due to kelp fronds, complex habitat

180 structures with large boulders or rocky outcrops, and high turbidity, thus limiting visibility from 
181 one structure to the next. Field work was conducted under the resolution 2,649 from

182 "Subsecretaría de Pesca y Acuicultura" (SUBPESCA) published in the "Diario Oficial de la

183 Republica de Chile”, num. 41,553 on 7 September 2016.

Fish species richness, frequency of occurrence and maximum abundance

We used video recordings to compare species richness (SR), frequency of occurrence (FO), and maximum abundance $(\mathrm{MaxN})$ of fish between habitats, and to determine the total number of species (total species richness) per site. In each recording, we registered fish species and their abundances every $30 \mathrm{sec}$ (video frame). When it was not possible to adequately scan a video frame (e.g. kelp blades in front of the camera), the closest visible frame was analysed. For horizontal videos, only fish observed within $<2 \mathrm{~m}$ distance from the camera (distance estimates based on reference points of the structures) were recorded, thereby generating a standardized survey area for all videos; there were no videos with a visibility of $<2 \mathrm{~m}$. We obtained a total of 81 videos for both habitat and structure types (for details, see Table S2).

SR was the number of species per video for each study site, FO was calculated as the proportion of frames in which the respective species was observed over the total number of frames analysed in each video (80 frames; providing information about residence or staying time), and MaxN was the maximum number of individuals of the respective species in a video (recorded in one of the 80 examined frames, i.e. there is only one value of MaxN per species per video), which provides information about the relative abundance of the given species at the study site (Cappo et al., 2003). All fishes were identified to species based on their shape, colour, and swimming habits, with the exception of Scartichthys, of which two species occur in the study area, $S$. viridis and $S$. gigas. These species are common in northern Chile and display variable 
204 colour patterns (Méndez-Abarca \& Mundaca, 2016), making it sometimes difficult to distinguish

205 among them, especially in videos with limited visibility. As both species are of similar size and

206 ecological habits, we treated them as Scartichthys viridis/gigas (see also Villegas et al., 2018).

207 To standardize the recordings, only the initial $40 \mathrm{~min}$ of each video were used (see also Willis \&

208 Babcock, 2000), obtaining 80 frames for counting data. This standardization was done for the

209 analysis of SR, FO and MaxN, all with one single data point per video for analyses. Species

210 accumulation curves for the two types of habitat confirmed that mean number of species

211 recorded with the videos approached an asymptote before $40 \mathrm{~min}$ (Figure S2), a time frame also

212 confirmed for a similar study system by Harasti et al. (2015). Only total species richness and

213 predation events were assessed using the entire duration of the videos.

214

215

\section{Predation assays and identity of predators}

216 We measured predation pressure using tethered prey organisms (T. niger and P. laevigatus) as

217 bait. Tethering has been used in different types of communities and with various types of prey,

218 including snails (Reynolds et al., 2018), crustaceans (Heck \& Wilson, 1987; Gutow et al., 2012;

219 Ory et al., 2012), sea urchins (Urriago et al., 2011, 2012), and fishes (Pérez-Matus et al., 2016).

220 Since refuge availability, prey behaviour, and other variables can affect the outcome of tethering

221 assays, these should only be used to assess relative predation or predation pressure within the

222 same ecosystem; following those basic recommendations (as done in our study) tethering assays

223 continue to be a useful tool for comparing the predation rates among different habitats or

224 environments (Aronson \& Heck, 1995).

As small sea urchins tend to be susceptible to predation (McClanahan, 1988), juvenile sea

urchins $T$. niger (15 - $25 \mathrm{~mm}$ test diameter) were tethered with monofilament fishing line $(0.15$ 
227 mm diameter) according to the methodology used by McClanahan \& Muthiga (1989) and

228 McClanahan \& Shafir (1989). The porcelanid crab P. laevigatus was included in our study for

229

230

231

232

233

234

235

236

237

238

239

240

241

242

243

244

245

246

247

248 comparative purposes, because along the Chilean coast decapod crustaceans are more frequent prey than sea urchins in the diet of common fish predators from subtidal hard bottoms (PérezMatus et al., 2012). Thus, this crab was used to validate background predation in the study area. Individuals of $P$. laevigatus (15-20 mm of cephalothorax) were tethered by gluing a piece of monofilament to the carapace with cyanoacrylate glue. Preliminary experiments of $24 \mathrm{~h}$ duration were run in laboratory tanks with tethered individuals, and neither mortality (because of the tether) nor escapes were observed.

Prey organisms were tethered on eternit plates to provide a uniform surface to prey and predators across different types of habitats; this way different refuge structures and prey hiding behaviour in the two habitat types would not interfere with the estimates of predation pressure. After 24 hours, missing prey items were counted for each structure and divided by the total number of baits ( $\mathrm{n}=6$ per structure), obtaining the proportion consumed. Using video recordings, we also identified predator species that consumed either sea urchins or crabs. It should be noted that data about predation events (from videos) only included the period until the cameras stopped recording (after $\sim 40-60$ minutes), and we may not have identified all species that might have fed on our prey organisms during the $24 \mathrm{~h}$ of consumption assays.

\section{Data analyses}

We analysed fish species richness, FO and MaxN separately for vertical and horizontal structures, considering the differences in the view field of each structure. The predation data after 
$24924 \mathrm{~h}$ were pooled for both structures, because the plate areas with attached prey organisms were

250 the same, irrespective of the structure.

251 For analysis, data from the two sampling days were pooled (see also above). All

252 procedures were performed through stepwise model selection on the raw data, according to

253 methods from Zuur et al. (2009). Species richness data were contrasted between habitats and

254 sites using generalized linear models (GLM), pooling video data from both prey species;

255 consumption was contrasted between habitat and prey using GLM, pooling video data from the

256 two different structures; and FO and MaxN were contrasted between habitat and prey types using

257 generalized linear mixed models (GLMMs), considering the values of FO or MaxN, respectively,

258 of each species per video as duplicates. GLMMs allowed us to account for our unbalanced, over-

259 dispersed and zero-inflated data set (Zuur et al., 2009). In GLMM analyses, we included habitat

260 and prey type as fixed factors; and sites, fish species, and individual observations (replicates)

261 were included as random factors. Zero inflation structure in FO GLMMs was attributed to habitat

262 and prey type, whereas in MaxN GLMMs it was only attributed to habitat. Sample replicates

263 were included as observational-level random effects in order to account for overdispersion, as

264 recommended by Bolker et al. (2009). The best model fit was selected based on the lowest

265 corrected Akaike Information Criterion (AICc) value. Model validation was then evaluated

266 through graphical observations of the normality of residuals and the relationship between both

267 observed and standardized residuals against fitted values (Bolker et al., 2009; Zuur et al., 2009).

268 All best-fit model validations exhibited an acceptable relationship of residuals against

269 fitted values. Most residuals were normally distributed, while observed residual against fitted

270 values did not show any pattern. However, subtle heterogeneities in standardized residuals 
271 against fitted values were observed in some cases. Additional structural-zeros were not predicted

272 for any of the final best-fit models.

273 Statistical analyses and graphics were done using the R environment (R core team 2019),

274 and its libraries glmmTMB (Brooks et al., 2017), AICcmodavg (Mazerolle, 2019), DHARMa

275 (Hartig, 2018), ggplot2 (Wickham, 2016), and MASS (Venables \& Ripley, 2002).

276

277

Results

278

279

280

281

282

283

284

285

286

287

288

289

290

291

292

293

\section{Fish species richness, frequency of occurrence and maximum abundance}

We observed a total of 11 fish species analysing the entire video duration, 10 species in kelp forests and 8 on barren grounds (Figure 3). A species that was absent in kelp forests was Paralabrax humeralis, which was only observed at BG-PC, while the following species were not recorded on barren grounds: Graus nigra, Semicossyphus darwini and Acanthistius pictus. The latter two were only observed at KF-CA. The highest total number of species ( 9 species) were observed in the CA kelp forest, while only 4 species were seen on the GU barren ground. For PC and $\mathrm{CH}$, where both habitats were present, $\mathrm{BG}$ and $\mathrm{KF}$ had similar total species richness (6 and 5 species, respectively, in both locations, Figure 3).

$\mathrm{SR}$ (mean \pm standard deviation) ranged from $1.2 \pm 0.4$ fish species in the $\mathrm{CH}$ kelp forest to $2.8 \pm 1.6$ in the CA kelp forest. The low values of SR were due to videos in which only one or two species were observed (see the dots in Figure 4). SR was similar between locations and habitats, both for videos with vertical and horizontal view (Figure 4, Table S4).

Scartichthys viridis/gigas was the most abundant species, followed by Pinguipes chilensis and Cheilodactylus variegatus, in both vertical and horizontal videos (Figure 5). Scartichthys viridis/gigas and $P$. chilensis used to be the first species to arrive in the visual field of the

Peer) reviewing PDF | (2019:02:34834:1:1:NEW 3 Apr 2019) 
294 cameras (in both habitats). It was very common to see these species within seconds after the

295 structure was deployed, or even when the diver was still there. Other, less common species were

296 observed in videos within minutes after deployment.

297 For vertical videos, there were no differences in FO between prey types, although barren

298 grounds were significantly different from kelp forests (Wald $\mathrm{z}=4.625$, df residual $=359, \mathrm{p}<$

299 0.001). In addition, random effects were largely determined by fish species variance (Table S6).

300 For horizontal videos, we also found no differences in FO between prey types and FO was higher

301 on barren grounds (Wald $\mathrm{z}=2.311$, $\mathrm{df}$ residual $=341, \mathrm{p}=0.0208$ ). Random effects were again

302 determined by fish species variance (Table S7). For the FO of three species that generated the

303 greatest random effect, $S$. viridis/gigas and $P$. chilensis reached higher values on barren grounds

304 (mainly in vertical videos), whereas $C$. variegatus mostly had higher values of FO in kelp forests

305 (Figure 5). Other predatory species, although present, occurred very infrequently, seen only in

306 one video or in few frames.

307

MaxN for the same three most abundant predatory fish species followed a similar pattern

as for FO, both in vertical and horizontal videos. For vertical videos, prey type did not exhibit a

significant effect, although barren grounds were significantly different from kelp forests (Wald

$\mathrm{z}=4.793$, df residual $=360, \mathrm{p}<0.001)$. Random effects were again largely determined by fish

species variance (Table S8). For horizontal videos, there was no effect of prey type, although

barren grounds exhibited marginal differences with kelp forests (Wald $\mathrm{z}=2.032$, df residual $=343$,

$\mathrm{p}=0.0422$ ). Random effects were determined by fish species, although its variance was the

smallest among the three previous analyses (Table S9). MaxN of Scartichthys viridis/gigas and among study sites. 
fishes were smaller than the plates $(40 \mathrm{~cm}$ side length) to which prey items were tethered. The

319

320

321

322

323

324

325

326

327

328

329

individuals of Pinguipes chilensis seen near the plates in videos were $\sim 20$ to $30 \mathrm{~cm}$ in body

length. In the less abundant species Graus nigra, all individuals were juveniles of $\sim 30 \mathrm{~cm}$. Also, during the deployment of structures, no large individuals of these species were seen by the divers.

\section{Predation assays and identity of predators}

Predation pressure for both prey species did not vary across locations and habitats, but significant differences were observed between sea urchin and crab consumption. Predation of porcelanid crabs was significantly higher than that of sea urchins (Wald $z=-6.396, \mathrm{df}$ residual $=116, \mathrm{p}<0.001$, Table $\mathrm{S} 10)$. Consumption of $T$. niger ranged from $8.3 \pm 14.2 \%$ on $\mathrm{CH}$ barren grounds to $29.6 \pm 28.6 \%$ on GU barren grounds (Figure 7a). In contrast, predation of porcelanid crabs ranged from $38.3 \pm 34.3 \%$ in the PC kelp forest to $86.7 \pm 31.2 \%$ on $\mathrm{CH}$ barren grounds (Figure 7b).

Scartichthys viridis/gigas and C. variegatus were seen preying on bait in video recordings (Table S3). Scartichthys viridis/gigas was the principal consumer of crabs $(82 \%$ of consumed prey) preying on 25 individuals of $P$. laevigatus on barren grounds and 7 individuals in kelp forests. Scartichthys viridis/gigas was also the only fish species recorded attacking (but not consuming) Tetrapygus niger. It was observed in 3 instances turning over sea urchins (solitary individuals) and attacking them orally on $\mathrm{CH}$ and $\mathrm{PC}$ barren grounds. One instance each of predation by the brachyuran crabs Homalaspis plana and Romaleon setosum was observed, consuming sea urchins T. niger on PC barren grounds. Additionally, a predation event by the 
340

341

342

\section{Discussion}

344

gastropod Concholepas concholepas over P. laevigatus was observed by the diver when cameras were removed (two hours after deployment), but this was not recorded in videos.

Fish species richness showed no major differences across locations and habitats, contrary to what was expected (higher richness in kelp forests). Values of FO and MaxN showed minor differences between habitats, which when observed, were higher on barren grounds than in kelp forests. These differences were mainly due to the presence of two abundant species Scartichthys viridis/gigas and Pinguipes chilensis, while other large fish predators occurred very infrequently. Predation on Petrolisthes laevigatus was significantly higher than on Tetrapygus niger, possibly because crabs are a major diet component of coastal fishes, or because large predatory fish that could have consumed the sea urchins were mostly absent. Scartichthys viridis/gigas was the principal predator identified in this study, mainly consuming crabs; it was also the only fish that was observed attacking $T$. niger, confirming the predatory character of this species. Total consumption after $24 \mathrm{~h}$ was similar between habitats, coinciding with the minor or lack of differences in MaxN and FO. Our findings suggest that $T$. niger might have increased in abundances on subtidal hard bottoms, because current predation pressure on this species is low, possibly due to overall reduced abundances of large, top fish predators.

\section{Fish communities}

Fish assemblages observed here were composed of typical species from the Chilean coast. The comparatively low total number of fish species per site was similar to species richness of reeffish observed by other studies along the central and northern coast of Chile (Gelcich et al., 2008; 
363 Ory et al., 2012; Villegas et al., 2018). Pérez-Matus et al. (2007) studied the structure of fish

364 assemblages in northern Chile and found that CA was the site with the highest species richness.

365 This site was also the location with the highest total number of species in our study, but when

366 comparing average SR per video among study sites, no differences were observed. SR did not

367 vary across locations and habitats, except for vertical videos where species richness was higher

368 on barren grounds. This is not totally unexpected, because although kelp forests usually have

369 higher diversity than other types of communities (Levin \& Hay, 1996; Graham, 2004), a recent

370 study in New Zealand also observed higher species richness, abundance and predation pressure

371 by fish on barren grounds than in kelp forests (Hesse et al., 2016). On the other hand, Angel \&

372 Ojeda (2001) observed similar values in coastal fish abundances and diversity in northern Chile,

373 when comparing a site with kelp forest and a site without forest.

$374 \quad$ Scartichthys viridis/gigas and Pinguipes chilensis were the most abundant species at all

375 study sites, being more frequent on barren grounds albeit with small differences in horizontal

376 videos (wider field of view). Scartichthys viridis/gigas are comparatively small fishes (10 - 20

$377 \mathrm{~cm}$ adult size) that are not commercially fished (Méndez-Abarca \& Mundaca, 2016) and are very

378 common in subtidal habitats of northern Chile (Villegas et al., 2018; this study). On the other

379 hand, P. chilensis was consistently present on barren grounds but not in kelp forests, which

380 appears to be typical for this species, since previous studies had observed that its abundances

381 increase when density of kelp forests decreases (Pérez-Matus et al., 2007). The third most

382 abundant predatory species was Cheilodactylus variegatus, which despite being more common in

383 kelp forests (Angel \& Ojeda, 2001; Pérez-Matus et al., 2007; Villegas et al., 2018) did not show

384 statistical differences in this study. 
Chile were rarely seen in our study (e.g. Hemilutjanus macrophthalmos, Graus nigra and

387

388

389

Semicossyphus darwini; Pérez-Matus et al., 2012), possibly due to low abundances caused by high fishing pressure (Godoy et al., 2010, 2016). It should be noted that the method often used for the determination of species richness are visual transect surveys (e.g. Pérez-Matus et al., 2007; Ory et al., 2012). Static recordings (video), as used in our study, could underestimate richness and abundances, because less abundant or less mobile species will be less frequently seen compared to visual transect surveys covering more extensive areas (Pérez-Matus et al., 2007). This could be partly responsible for the low abundances observed; indeed, we generally observed higher abundances in the horizontal videos with wider visual field. On the other hand, visual surveys may underestimate the presence and abundance of fish species with cryptic behaviours (Willis, 2001), such as $S$. viridis/gigas, the most frequent and abundant species in our study. Using both methods (visual transect surveys, and BRUVs) in the same study could provide the best estimates of species richness and abundance of demersal fishes, since biology and behaviour of studied species could affect results when using different census methods (Willis et al., 2000).

\section{Predation rates across communities}

We observed no significant differences in predation rates between habitats for both prey species, which also coincides with findings of similar fish assemblages in kelp forests as well as on barren grounds. On the other hand, consumption was very different between the two prey species, with crabs being much more consumed than sea urchins. This was somewhat expected because crustaceans have a greater index of relative abundance in the stomach contents of 
408 temperate reef fishes (Vargas et al., 1999; Medina et al., 2004; Pérez-Matus et al., 2012), thus

409 being preferred over sea urchins. However, although echinoderms are not the most consumed

410 prey items, they are frequently found in the stomach contents of these fish. The more abundant

411 predators (Scartichthys viridis/gigas and Pinguipes chilensis) were ineffective in consuming sea

412 urchins, while the other less abundant species (e.g. Graus nigra, Semicossyphus darwini, or

413 Cheilodactylus variegatus) are recognized as important top predators along the Chilean coast

414 (Pérez-Matus et al., 2007; Pérez-Matus et al., 2017b). Indeed, Selden et al. (2017) described a

415 direct relationship between the rate of sea urchin consumption and the size of the predatory fish

416 Semicossyphus pulcher in California. The lack of large individuals of S. darwini and similar fish

417 predators in our study area could thus be an explanation for low predation pressure on sea

418 urchins, thereby ultimately being responsible for their proliferation and the establishment of

419 extensive barren grounds along the coast of northern Chile.

420 Seasonality could also affect results since this study was done over a year. Seasonal

421 temperature variations may affect metabolic rates of organisms (Brown et al., 2004; Milazzo et

422 al., 2013), and thereby influence their predation rates (Duffy et al., 2015). However, seasonal

423 temperature variation along the exposed coast of Chile are rather moderate (Thiel et al., 2007)

424 and might be insufficient to generate metabolic shifts in consumers as has been described for

425 other latitudes (Brown et al., 2004). Furthermore, fish assemblages in the study region are similar

426 across different seasons and fish species are characterized as being territorial and non-migratory

427 (Angel \& Ojeda, 2001; Pérez-Matus et al., 2007; Pérez-Matus et al., 2012). Consequently, it is

428 unlikely that fish abundances and predation rates are affected by the season.

Scartichthys viridis/gigas was the species that consumed the most prey during video

recordings. This species has originally been described as an herbivorous species with more than 
$43190 \%$ of their stomach contents comprising seaweeds, mostly chlorophytes and rhodophytes

432 (Ojeda \& Muñoz, 1999; Muñoz \& Ojeda, 2000). However, those studies were conducted on

433 individuals from the intertidal zone, with little information on the foraging behaviour of this

434 species in subtidal habitats. Ory et al. (2012) observed effective predation events of S. viridis on

435 Rhynchocinetes typus in the shallow subtidal zone: the initial attack of an individual, usually

436 adult, triggers a series of joint attacks by multiple conspecifics, forming a kind of feeding frenzy,

437 which ends when the prey item is completely consumed. Similar observations had already been

438 reported by Dumont et al. (2011), classifying S. viridis as the most efficient predator on the

439 ascidian Ciona intestinalis within the Coastal System of Coquimbo $\left(30^{\circ} \mathrm{S}\right)$. Our study not only

440 confirms active predation but also group foraging in S. viridis/gigas. However, similar to reports

441 by Urriago et al. (2012), S. viridis/gigas attacked and damaged T. niger but did not achieve

442 successful predation in our videos. Whether the frenzy generated by this blennid fish might

443 attract other predators of sea urchins is not known at present.

444 Cheilodactylus variegatus was the only other predatory fish preying on our baits,

445 specifically on crabs, which is consistent with previous studies that observed porcelanid crabs in

446 the diet of this species (Angel \& Ojeda, 2001; Palma \& Ojeda, 2002; Pérez-Matus et al., 2012).

447 There are several other fish species that could have preyed on our baits, such as G. nigra, $S$.

448 darwini, H. macrophthalmos and P. chilensis, among others (Muñoz \& Ojeda, 1997; Medina et

449 al., 2004; Pérez-Matus et al., 2012). These species, which could potentially be predators and

450 controllers of sea urchins, were not identified as predators, most likely because they were only

451 observed in low abundances in our study (except for P. chilensis). Possibly, low abundances and

452 the small sizes of adult fishes observed in our videos (see also Selden et al., 2017) are the main

453 reason for not recording them to prey on our baits. On the other hand, some of the species that 
454 consumed our prey (during the $24 \mathrm{~h}$ of the assay) may have nocturnal behaviours and were thus 455 not captured by our diurnal video recordings.

In addition to fish predators, seastars Heliaster helianthus and Meyenaster gelatinosus are

457

458

459

460

461

462

463

464

465

466

467 Conclusion

468

469

470

471

472

473

474

475

476

among the main consumers of sea urchins (Gaymer \& Himmelman, 2008; Urriago et al., 2011, 2012), but in our study they seemed to be unimportant, not being interested in the tethered prey. On the other hand, brachyuran crabs Homalaspis plana and Romaleon setosum were observed attacking (and successfully preying on) tethered sea urchins. While our study is focused on fish predators, crabs also might be important controllers of black sea urchins, an interpretation that is supported by previous studies that have recognized these species as consumers of echinoids (Morales \& Antezana, 1983; Cerda \& Wolff, 1993). Future studies of subtidal predator assemblages should also take carnivorous crabs into account, because they seem to have an important role in subtidal rocky reefs.

We observed no differences in predation pressure between habitats, which could be related to the similar species richness and abundances of the observed fishes. We also recorded very low abundances of important top fish predators at all sites (e.g. Semicossyphus darwini), which might be due to overfishing (Godoy et al., 2010; Godoy et al., 2016) or due to the method used to count (stationary videos). The overall lack of large fish predators may also facilitate small and opportunistic predators such as Scartichthys viridis/gigas (not subject to fishing), which have been observed in this study as important predators in both habitats, kelp forests and barren grounds. The fact that these small fish were frequently observed in open areas during bright daylight furthermore suggests that large predatory fish are rare in the study area, which could 
477 also have favoured sea urchin survival and spreading on subtidal hard bottoms. In summary, high

478 fishing pressure and the consequent lack of top fish predators may have profound effects on

479 shallow subtidal communities along the Chilean coast. This needs further attention, considering

480 the ecological importance of kelp forests and their increasing exploitation (Almanza \&

481 Buschmann, 2013; Buschmann et al., 2014).

482

483

\section{Acknowledgements}

484

485

486

487

488

489

490

491

492

493

494

495

496

497

498

499

We are foremost grateful to the fishermen who allowed us to work in their AMERBs. We thank the boat people, and especially Freddy Gonzalez, for their help during this study. We are very grateful to Miles Abadilla for editing the final manuscript. We also thank Boris López, who helped with the maps in figure 1.

\section{References}

Almanza V, Buschmann AH, Hernández-González MC, Henríquez LA. 2012. Can giant kelp (Macrocystis pyrifera) forests enhance invertebrate recruitment in southern Chile? Marine Biology Research 8:855-864. https://doi.org/10.1080/17451000.2012.692159

Almanza V, Buschmann AH. 2013. The ecological importance of Macrocystis pyrifera (Phaeophyta) forests towards a sustainable management and exploitation of Chilean coastal benthic co-management areas. International Journal of Environment and Sustainable Development 12:341-360. https://doi.org/10.1504/IJESD.2013.056331

Angel A, Ojeda FP. 2001. Structure and trophic organization of subtidal fish assemblages on the northern Chilean coast: the effect of habitat complexity. Marine Ecology Progress Series 217:81-91. https://doi.org/10.3354/meps217081 
500 Aronson RB, Heck Jr KL. 1995. Tethering experiments and hypothesis testing in ecology.

501 Marine Ecology Progress Series 121:307-309. https://doi.org/10.3354/meps121307

502 Brown JH, Gillooly JF, Allen AP, Savage VM, Geoffrey BW. 2004. Toward a metabolic

503 theory of ecology. Ecology 85:1771-1789. https://doi.org/10.1890/03-9000

504 Bolker BM, Brooks ME, Clark CJ, Geange SW, Poulsen JR, Stevens MH, White JS. 2013.

505 Generalized linear mixed models: a practical guide for ecology and evolution. Trends in Ecology 506 and Evolution 24:127-135.

507 Brooks ME, Kristensen K, van Benthem KJ, Magnusson A, Berg CW, Nielsen A, Skaug

508 HJ, Maechler M, Bolker BM. 2017. glmmTMB balances speed and flexibility among packages

509 for zero-inflated Generalized Linear Mixed Modeling. The R Journal 9: 378-400.

510 Buschmann AH, Prescott S, Potin P, Faugeron S, Vasquez JA, Camus C, Infante J,

511 Hernández-González MC, Gutíerrez A, Varela DA. 2014. The status of kelp exploitation and

512 marine agronomy, with emphasis on Macrocystis pyrifera, in Chile. Advances in Botanical

513 Research 71:161-188. http://doi.org/10.1016/B978-0-12-408062-1.00006-8

514 Camus PA. 2001. Biogeografía marina de Chile continental. Revista Chilena de Historia

515 Natural 74:587-617. http://doi.org/10.4067/S0716-078X2001000300008

516 Cappo M, Harvey E, Malcolm H, Speare P. 2003. Potential of video techniques to monitor

517 diversity, abundance and size of fish in studies of Marine Protected Areas. in: Beumer JP, Grant

518 A, Smith DC (Eds.). Aquatic Protected Areas-what works best and how do we know? Australian

519 Society of Fish Biology, Cairns, Australia. 455-464.

520 Cerda G, Wolff M. 1993. Feeding ecology of the crab Cancer polyodon in La Herradura Bay,

521 northern Chile. II. Food spectrum and prey consumption. Marine Ecology Progress Series

522 100:119-125. https://doi.org/10.3354/meps100119 
523 Clemente S, Hernández JC, Rodríguez A, Brito A. 2010. Identifying keystone predators and

524 the importance of preserving functional diversity in sublittoral rocky-bottom areas. Marine

525 Ecology Progress Series 413:55-67. https://doi.org/10.3354/meps08700

526 Dayton PK. 1985. The structure and regulation of some South American kelp communities.

527 Ecological Monographs 55:447-468. https://doi.org/10.2307/2937131

528 Duffy JE, Ziegler SL, Campbell JE, Bippus PM, Lefcheck JS. 2015. Squidpops: A simple

529 tool to crowdsource a global map of marine predation intensity. PLOS ONE 10:e0142994.

530 https://doi.org/10.1371/journal.pone.014299

531 Dumont CP, Gaymer CF, Thiel M. 2011. Predation contributes to invasion resistance of

532 benthic communities against the non-indigenous tunicate Ciona intestinalis. Biological Invasions

533 13:2023-2034. https://doi.org/10.1007/s10530-011-0018-7

534 Foster MS, Schiel DR. 2010. Loss of predators and the collapse of southern California kelp

535 forests (?): Alternatives, explanations and generalizations. Journal of Experimental Marine

536 Biology and Ecology 393:59-70. https://doi.org/10.1016/j.jembe.2010.07.002

537 Gaymer CF, Himmelman JH. 2008. A keystone predatory sea star in the intertidal zone is

538 controlled by a higher-order predatory sea star in the subtidal zone. Marine Ecology Progress

539 Series 370:143-153. https://doi.org/10.3354/meps07663

540 Gelcich S, Godoy N, Prado L, Castilla JC. 2008. Add-on conservation benefits of marine

541 territorial user rights fishery policies in central Chile. Ecological Applications 18:273-281.

542 https://doi.org/10.1890/06-1896.1

543 Godoy N, Gelcich S, Vásquez JA, Castilla JC. 2010. Spearfishing to depletion: evidence from

544 temperate reef fishes in Chile. Ecological Applications 20:1504-1511.

545 https://doi.org/10.1890/09-1806.1 
546 Godoy N, Gelcich S, Castilla JC, Lima M, Smith A. 2016. Artisanal spearfishery in temperate

547 nearshore ecosystems of Chile: Exploring the catch composition, revenue, and management

548 needs. Marine and Coastal Fisheries: Dynamics, Management, and Ecosystem Science 8:436-

549 447. https://doi.org/10.1080/19425120.2016.1185062

550 Graham MH. 2004. Effects of local deforestation on the diversity and structure of southern

551 California giant kelp forest food webs. Ecosystems 7:341-357 https://doi.org/10.1007/s10021-

$552 \underline{003-0245-6}$

553 Graham MH, Vásquez JA, Buschmann AH. 2007. Global ecology of the giant kelp

554 Macrocystis: from ecotypes to ecosystems. Oceanography and Marine Biology - an Annual

555 Review 45:39-88.

556 Guidetti P, Fraschetti S, Terlizzi A, Boero F. 2003. Distribution patterns of sea urchins and

557 barrens in shallow Mediterranean rocky reefs impacted by the ilegal fishery of the rock-boring

558 mollusc Lithophaga lithophaga. Marine Biology 143:1135-1142.

559 Guidetti P. 2006. Marine reserves reestablish lost predatory interactions and cause community

560 changes in rocky reefs. Ecological Applications 16:963-976. https://doi.org/10.1890/1051-

$561 \quad$ 0761(2006)016[0963:MRRLPI]2.0.CO;2

562 Gutow L, Long JD, Cerda O, Hinojosa IA, Rothäusler E, Tala F, Thiel M. 2012. Herbivorous

563 amphipods inhabit protective microhabitats within thalli of giant kelp Macrocystis pyrifera.

564 Marine Biology 159:141-149. https://doi.org/10.1007/s00227-011-1794-4

565 Halpern BS, Cottenie C, Broitman BR. 2006. Strong top-down control in southern California

566 kelp forest ecosystems. Science 312:1230-1232. https://doi.org/10.1126/science.1128613 
567 Hamilton SL, Caselle JE. 2015. Exploitation and recovery of a sea urchin predator has

568 implications for the resilience of southern California kelp forests. Proceedings of the Royal

569 Society B 282:20141817. http://doi.org/10.1098/rspb.2014.1817

570 Harasti D, Malcolm H, Gallen C, Coleman MA, Jordan A, Knott NA. 2015. Appropriate set

571 times to represent patterns of rocky reef fishes using baited video. Journal of Experimental

572 Marine Biology and Ecology 463:173-180. https://doi.org/10.1016/j.jembe.2014.12.003

573 Hargrave MS, Foggo A, Pessarrodona A, Smale DA. 2017. The effects of warming on the

574 ecophysiology of two co-existing kelp species with contrasting distributions. Oecologia 183:531-

575 543. https://doi.org/10.1007/s00442-016-3776-1

576 Hartig, F. 2018. DHARMa: Residual Diagnostics for Hierarchical (Multi-Level / Mixed)

577 Regression Models. R package version 0.2.0. https://CRAN.R-project.org/package=DHARMa

578 Hauser A, Attrill MJ, Cotton PA. 2006. Effects of habitat complexity on the diversity and

579 abundance of macrofauna colonising artificial kelp holdfasts. Marine Ecology Progress Series

580 325:93-100. https://doi.org/10.3354/meps325093

581 Heck KL, Wilson KA. 1987. Predation rates on decapod crustaceans in latitudinally separated

582 seagrass communities: a study of spatial and temporal variation using tethering techniques.

583 Journal of Experimental Marine Biology and Ecology 107:87-100. https://doi.org/10.1016/0022-

$584 \quad \underline{0981(87) 90188-2}$

585 Henríquez LA, Buschmann AH, Maldonado MA, Graham MH, Hernández-González MC,

586 Pereda SV, Bobadilla MI. 2011. Grazing on giant kelp microscopic phases and the recruitment

587 success of annual population of Macrocystis pyrifera (Laminariales, Phaeophyta) in southern

588 Chile. Journal of Phycology 47: 252-258. 
589 Hesse J, Stanley JA, Jeffs AG. 2016. Do predatory fish of benthic crustaceans vary between

590 kelp and barren reef habitats in northeastern New Zealand? New Zealand Journal of Marine and

591 Freshwater Research 50:339-357. https://doi.org/10.1080/00288330.2016.1146309

592 Jackson JBC, Kirby MX, Berger WH, Bjorndal KA, Botsford LV, Bourque BJ, Bradbury

593 RH, Cooke R, Erlandson J, Estes JA, Hughes TP, Kidwell S, Lange CB, Lenihan HS,

594 Pandolfi JM, Peterson CH, Steneck RS, Tegner MJ, Warner RR. 2001. Historical

595 overfishing and the recent collapse of coastal ecosystems. Science 293:629-637.

596 https://doi.org/10.1126/science.1059199

597 Konar B, Edwards MS, Estes JA. 2014. Biological interactions maintain the boundaries

598 between kelp forests and urchin barrens in the Aleutian Archipelago. Hydrobiologia 724:91-107.

599 https://doi.org/10.1007/s10750-013-1727-y

600 Krumhansl KA, Okamoto, DK, Rassweiler A, Novak M, Bolton JJ, Cavanaugh KC, Conell

601 SD, Johnson CR, Konar B, Ling SD, Micheli F, Norderhaug KM, Pérez-Matus A, Souza-

602 Pinto I, Reed DC, Salomon AK, Shears NT, Wernberg T, Anderson RJ, Barrett NS,

603 Buschmann AH, Carr MH, Caselle JE, Darrien-Courtel S, Edgar GJ, Edwards M, Estes

604 JA, Goodwin C, Kenner MC, Kushner DJ, Moy FE, Nunn J, Steneck RS, Vásquez J,

605 Watson J, Witman JD, Byrnes JEK. 2016. Global patterns of kelp forest change over the past

606 half-century. Proceedings of the National Academy of Sciences of the United States of America

607 113:13785-13790. https://doi.org/10.1073/pnas.1606102113

608 Leleu K, Remy-Zephir B, Grace R, Costello MJ. 2012. Mapping habitats in a marine reserve

609 showed how a 30-year trophic cascade altered ecosystem structure. Biological Conservation

610 155:193-201. https://doi.org/10.1016/j.biocon.2012.05.009 
611 Levin PS, Hay M. 1996. Responses of temperate reef fishes to alterations in algal structure and 612 species composition. Marine Ecology Progress Series 134:37-47.

613 Malcolm HA, Gladstone W, Lindfield S, Wraith J, Lynch TP. 2007. Spatial and temporal 614 variation in reef fish assemblages of marine parks in New South Wales, Australia — baited video 615 observations. Marine Ecology Progress Series 350:277-290. https://doi.org/10.3354/meps07195 616 Mazerolle, MJ. 2019. AICcmodavg: Model selection and multimodel inference based on 617 (Q)AIC(c). R package version 2.2-1. https://cran.r-project.org/package=AICcmodavg 618 McClanahan TR. 1988. Coexistence in a sea urchin guild and its implications to coral reef 619 diversity and degradation. Oecología 77:210-218. http://doi.org/10.1007/BF00379188

620 McClanahan TR, Muthiga NA. 1989. Patterns of preedation on a sea urchin, Echinometra 621 mathaei (de Blainville), on Kenyan coral reefs. Journal Experimental Marine Biology and 622 Ecology 126:77-94. https://doi.org/10.1016/0022-0981(89)90125-1

623 McClanahan TR, Shafir SH. 1989. Causes and consequences of sea urchin abundance and 624 diversity in Kenyan coral reef lagoons. Oecologia 83:362-370.

625 https://doi.org/10.1007/BF00317561

626 Medina M, Araya M, Vega C. 2004. Alimentación y relaciones tróficas de peces costeros de la 627 zona norte de Chile. Investigaciones Marinas 32:33-47. http://doi.org/10.4067/S0717-

$628 \quad \underline{71782004000100004}$

629 Medrano A, Linares C, Aspillaga E, Capdevila P, Montero-Serra I, Pagès-Escolà M, Hereu 630 B. 2019. No-take marine reserves control the recovery of sea urchin populations after mass 631 mortality events. Marine Environmental Research: in Press.

632 https://doi.org/10.1016/j.marenvres.2019.02.013 
633 Méndez-Abarca F, Mundaca EA. 2016. Colouration patterns of two species of the genus

634 Scartichthys (Blenniidae: Perciformes) in the coastal area of northern Chile. Revista de Biología

635 Marina y Oceanografía 51:475-481. http://doi.org/10.4067/S0718-19572016000200026

636 Milazzo M, Mirto S, Domenici P, Gristina M. 2013. Climate change exacerbates interspecific

637 interactions in sympatric coastal fishes. Journal of Animal Ecology 82:468-477.

638 https://doi.org/10.1111/j.1365-2656.2012.02034.x

639 Miller RJ, Lafferty KD, Lamy T, Kui L, Rassweiler A, Reed DC. 2018. Giant kelp,

640 Macrocystis pyrifera, increases faunal diversity through physical engineering. Proceedings of the

641 Royal Society B 285:20172571. https://doi.org/10.1098/rspb.2017.2571

642 Morales C, Antezana T. 1983. Diet selection of the Chilean stone crab Homalaspis plana.

643 Marine Biology 77:79-83. https://doi.org/10.1007/BF00393212

644 Muñoz AA, Ojeda FP. 1997. Feeding guild structure of a rocky intertidal fish assemblage in

645 central Chile. Environmental Biology of Fishes 49:471-479.

646 https://doi.org/10.1023/A:1007305426073

647 Muñoz AA, Ojeda FP. 2000. Ontogenetic changes in the diet of the herbivorous Scartichthys

648 viridis in a rocky intertidal zone in central Chile. Journal of Fish Biology 56:986-998.

649 https://doi.org/10.1111/j.1095-8649.2000.tb00887.x

650 Norderhaug KM, Christie HC. 2009. Sea urchin grazing and kelp re-vegetation in the NE

651 Atlantic. Marine Biology Research 5:515-528. https://doi.org/10.1080/17451000902932985

652 Ojeda P, Muñoz AA. 1999. Feeding selectivity of the herbivorous fish Scartichthys viridis:

653 effects on macroalgal community structure in a temperate rocky intertidal coastal zone. Marine

654 Ecology Progress Series 184:219-229. 
655 Oliver ECJ, Lago V, Hobday AJ, Holbrook NJ, Ling SD, Mundy CN. 2018. Marine

656 heatwaves off eastern Tasmania: Trends, interannual variability, and predictability. Progress in

657 Oceanography 161:116-130. https://doi.org/10.1016/j.pocean.2018.02.007

658 Ory NC, Dudgeon D, Dumont CP, Miranda L, Thiel M. 2012. Effects of predation and

659 habitat structure on the abundance and population structure of the rock shrimp Rhynchocinetes

660 typus (Caridea) on temperate rocky reefs. Marine Biology 159:075-2089.

661 https://doi.org/10.1007/s00227-012-1994-6

662 Palma ÁT, Ojeda FP. 2002. Abundance, distribution and feeding patterns of a temperate reef

663 fish in subtidal environments of the Chilean coast: the importance of understory algal turf.

664 Revista Chilena de Historia Natural 75:189-200. http://doi.org/10.4067/S0716-

$665 \underline{078 X 2002000100018 .}$.

666 Pérez-Matus A, Ferry-Graham LA, Cea A, Vásquez JA. 2007. Community structure of 667 temperate reef fishes in kelp-dominated subtidal habitats of northern Chile. Marine and 668 Freshwater Research 58:1069-1085. https://doi.org/10.1071/MF06200

669 Pérez-Matus A, Pledger S, Díaz FJ, Ferry LA, Vásquez JA. 2012. Plasticity in feeding 670 selectivity and trophic structure of kelp forest associated fishes from northern Chile. Revista

671 Chilena de Historia Natural 85:29-48. http://doi.org/10.4067/S0716-078X2012000100003

672 Pérez-Matus A, Sánchez F, González-But JC, Lamb RW. 2016. Understory algae

673 associations and predation risk influence broad-scale kelp habitat use in a temperate reef fish.

674 Marine Ecology Progress Series 559:147-158. https://doi.org/10.3354/meps11892

675 Pérez-Matus A, Carrasco SA, Gelcich S, Fernandez M, Wieters E. 2017a. Exploring the

676 effects of fishing pressure and upwelling intensity over subtidal kelp forest communities in

677 central Chile. Ecosphere 8: e01808.10.1002/ecs2.1808. https://doi.org/10.1002/ecs2.1808 
678 Pérez-Matus A, Ospina-Alvarez A, Camus PA, Carrasco SA, Fernandez M, Gelcich S,

679 Godoy N, Ojeda FP, Prado LM, Rozbaczylo N, Subida MD, Thiel M, Wieters EA,

680 Navarrete SA. 2017b. Temperate rocky subtidal reef community reveals human impacts across

681 the entire food web. Marine Ecology Progress Series 567:1-16.

682 https://doi.org/10.3354/meps 12057

683 Perreault MC, Borgeaud IA, Gaymer CF. 2014. Impact of grazing by the sea

684 urchin Tetrapygus niger on the kelp Lessonia trabeculata in northern Chile. Journal of

685 Experimental Marine Biology and Ecology 453:22-27.

686 https://doi.org/10.1016/j.jembe.2013.12.021

687 R Core Team. 2018. R: A language and environment for statistical computing. R Foundation for

688 Statistical Computing, Vienna, Austria. ISBN 3-900051-07-0. http://www.R-project.org/

689 (accessed 18 March 2019)

690 Reynolds PL, Stachowicz JJ, Hovel K, Boström C, Boyer K, Cusson M, Eklöf JS, Engel

691 FG, Engelen AH, Eriksson BK, Fodrie FJ, Griffin JN, Hereu C, Hori M, Hanley T, Ivanov

692 M, Jorgensen P, Kruschel C, Lee KS, McGlathery K, Moksnes PO, Nakaoka M, O'Connor

693 MI, O'Connor N, Orth RJ, Rossi F, Ruesink J, Sotka E, Tomas F, Unsworth RKF, Whalen

694 MA, Duffy JE. 2018. Latitude, temperature and habitat complexity predict predation pressure in

695 eelgrass beds across the northern Hemisphere. Ecology 99:29-35.

696 https://doi.org/10.1002/ecy.2064

697 Sala E, Zabala M. 1996. Fish predation and the structure of the sea urchin Paracentrotus lividus

698 populations in the NW Mediterranean. Marine Ecology Progress Series 140:71-81.

699 https://doi.org/10.3354/meps 140071 
700 Schettini R, Corchs S. 2010. Underwater image processing: State of the art of restoration and

701 image enhancement methods. EURASIP Journal on Advances in Signal Processing 746052.

702 http://doi.org/10.1155/2010/746052

703 Selden RL, Gaines SD, Hamilton SL, Warner RR. 2017. Protection of large predators in a

704 marine reserve alters size-dependent prey mortality. Proceedings of the Royal Society B 284:

705 20161936. http://doi.org/10.1098/rspb.2016.1936

706 Simonson EJ, Scheibling RE, Metaxas A. 2015. Kelp in hot water: I. Warming seawater

707 temperature induces weakening and loss of kelp tissue. Marine Ecology Progress Series 537:89-

708 104. https://doi.org/10.3354/meps11438

709

Steneck RS, Graham MH, Bourque BJ, Corbett D, Erlandson JM, Estes JA, Tegner MJ.

710 2002. Kelp forest ecosystems: biodiversity, stability, resilience and future. Environmental

711 Conservation 29:436-459. https://doi.org/10.1017/S0376892902000322

712 Stotz WB, Aburto J, Caillaux LM, González SA. 2016. Vertical distribution of rocky subtidal

713 assemblages along the exposed coast of north-central Chile. Journal of Sea Research 107:34-47.

714 https://doi.org/10.1016/j.seares.2015.11.006

715 Teagle H, Hawkins SJ, Moore PJ, Smale DA. 2017. The role of kelp species as biogenic

716 habitat formers in coastal marine ecosystems. Journal of Experimental Marine Biology and

717 Ecology 492:81-98. https://doi.org/10.1016/j.jembe.2017.01.017

718 Tegner MJ, Dayton PK. 1987. El Niño Effects on Southern California Kelp Forest

719 Communities. Advances in Ecological Research 17:243-279.

720 Tegner MJ, Dayton PK. 2000. Ecosystem effects of fishing in kelp forest communities. ICES

721 Journal of Marine Science 57:579-589. https://doi.org/10.1006/jmsc.2000.0715 
722 Thiel M, Macaya EC, Acuña E, Arntz WE, Bastias H, Brokordt K, Camus PA, Castilla JC,

723 Castro LR, Cortés M, Dumont CP, Escribano R, Fernández M, Gajardo JA, Gaymer CF,

724 Gómez I, González AE, González HE, Haye PA, Illanes JE, Iriarte JL, Lancellotti DA,

725 Luna-Jorquera G, Luxoroi C, Manríquez PH, Marín V, Muñoz P, Navarrete SA, Pérez E,

726 Poulin E, Sellanes J, Sepúlveda HH, Stotz W, Tala F, Thomas A, Vargas CA, Vásquez JA,

727 Vega JMA. 2007. The Humboldt current system of northern and central Chile: oceanographic

728 processes, ecological interactions and socioeconomic feedback. Oceanography and Marine

729 Biology: Annual Review 45:195-344.

730 Urriago JD, Himmelman JH, Gaymer CF. 2011. Responses of the black sea urchin

731 Tetrapygus niger to its sea-star predators Heliaster helianthus and Meyenaster gelatinosus under

732 field conditions. Journal of Experimental Marine Biology and Ecology 399:17-24.

733 https://doi.org/10.1016/j.jembe.2011.01.004

734 Urriago JD, Himmelman JH, Gaymer CF. 2012. Sea urchin Tetrapygus niger distribution on

735 elevated surfaces represents a strategy for avoiding predatory sea stars. Marine Ecology Progress

736 Series 444:85-95. https://doi.org/10.3354/meps09396

737 Vargas ME, Soto RA, Guzmán GL. 1999. Cambios interanuales en la alimentación de peces

738 submareales del norte de Chile entre los $20^{\circ} 11^{\prime}$ y $20^{\circ} 20^{\prime}$ S. Revista de Biología Marina y

739 Oceanografia 34:197-210.

740 Vásquez JA, Santelices B. 1990. Ecological effects of harvesting Lessonia (Laminariales,

741 Phaeophyta) in central Chile. Hydrobiologia 204/205:41-47.

742 https://doi.org/10.1007/BF00040213

743 Vásquez JA, Buschmann AH. 1997. Herbivore-kelp interactions in Chilean subtidal

744 communities: a review. Revista Chilena de Historia Natural 70:41-52. 
745 Vega JMA, Vásquez JA, Buschmann AH. 2005. Population biology of the subtidal kelps

746 Macrocystis integrifolia and Lessonia trabeculata (Laminariales, Phaeophyceae) in an upwelling

747 ecosystem of northern Chile: interannual variability and El Niño 1997-1998. Revista Chilena de

748 Historia Natural 78: 33-50. https://doi.org/10.4067/S0716-078X2005000100004

749 Venables WN, Ripley BD. 2002. MASS library of functions. Modern Applied Statistics with S.

750 Springer (Fourth Edition), New York. ISBN 0-387-95457-0. 495 p.

751 Villegas M, Laudien J, Sielfeld W, Arntz W. 2018. Effect of foresting barren ground with

752 Macrocystis pyrifera (Linnaeus) C. Agardh on the occurrence of coastal fishes off northern

753 Chile. Journal of Applied Phycology: in press, 1-13. https://doi.org/10.1007/s10811-018-1657-1

754 Wernberg T, Thomsen MS, Tuya F, Kendrick GA, Staehr PA, Toohey BD. 2010.

755 Decreasing resilience of kelp beds along a latitudinal temperature gradient: potential implications

756 for a warmer future. Ecology Letters 13:685-694. https://doi.org/10.1111/j.1461-

$757 \quad \underline{0248.2010 .01466 . x}$

758 Wernberg T, Smale DA, Tuya F, Thomsen MS, Langlois TJ, de Bettignies T, Benett S,

759 Rousseaux CS. 2013. An extreme climatic event alters marine ecosystem structure in a global

760 biodiversity hotspot. Nature Climate Change 3:78-82. https://doi.org/10.1038/nclimate1627

761 Wernberg T, Krumhansl K, Filbee-Dexter K, Pedersen MF. 2019. Status and trends for the

762 world's kelp forests. In: Sheppard C, ed. World Seas: An environmental evaluation. Academic

763 Press (Second Edition), 57-78. https://doi.org/10.1016/B978-0-12-805052-1.00003-6

764 Wickham, H. 2016. ggplot2: Elegant graphics for data analysis. Springer-Verlag (Second

765 Edition), New York. 260 p. https://doi.org/10.1007/978-0-387-98141-3

766 Willis TJ, Babcock RC. 2000. A baited underwater video system for the determination of

767 relative density of carnivorous reef fish. Marine and Freshwater Research 51:755-763. 
768 Willis TJ, Millar RB, Babcock RC. 2000. Detection of spatial variability in relative density of 769 fishes: comparison of visual census, angling, and baited underwater video. Marine Ecology

770 Progress Series 198:249-260.

771 Willis TJ. 2001. Visual census methods underestimate density and diversity of cryptic reef

772 fishes. Journal of Fish Biology 59:1408-1411. https://doi.org/10.1111/j.1095-

$773 \quad \underline{8649.2001 . t b 00202 . x}$

774 Zuur A, Ieno E, Walker N, Saveliev A, Smith G. 2009. Mixed effects models and extensions 775 in ecology with R. In: Gail M, Krickeberg K, Samet JM, Tsiatis A, Wong W, ed. Statistics for 776 biology and health. Springer Science, New York, 563p.

777

778

779

780 


\section{Figure 1}

Map of the 4 sampling locations along the Chilean coast and their corresponding habitats.

Black triangles indicate kelp forest sites at Caleta Angosta (CA), Punta de Choros (PC) and Chungungo $(\mathrm{CH})$ and black dots indicate barren ground sites at $\mathrm{PC}, \mathrm{CH}$, and Guayacancito (GU). All sites are within management areas (AMERBs), except for GU, which is an open access area. Images were extracted from Google Earth Pro program. Image (c 2018 Google, CNES/ airbus 2019, Terrametrics 2019. 


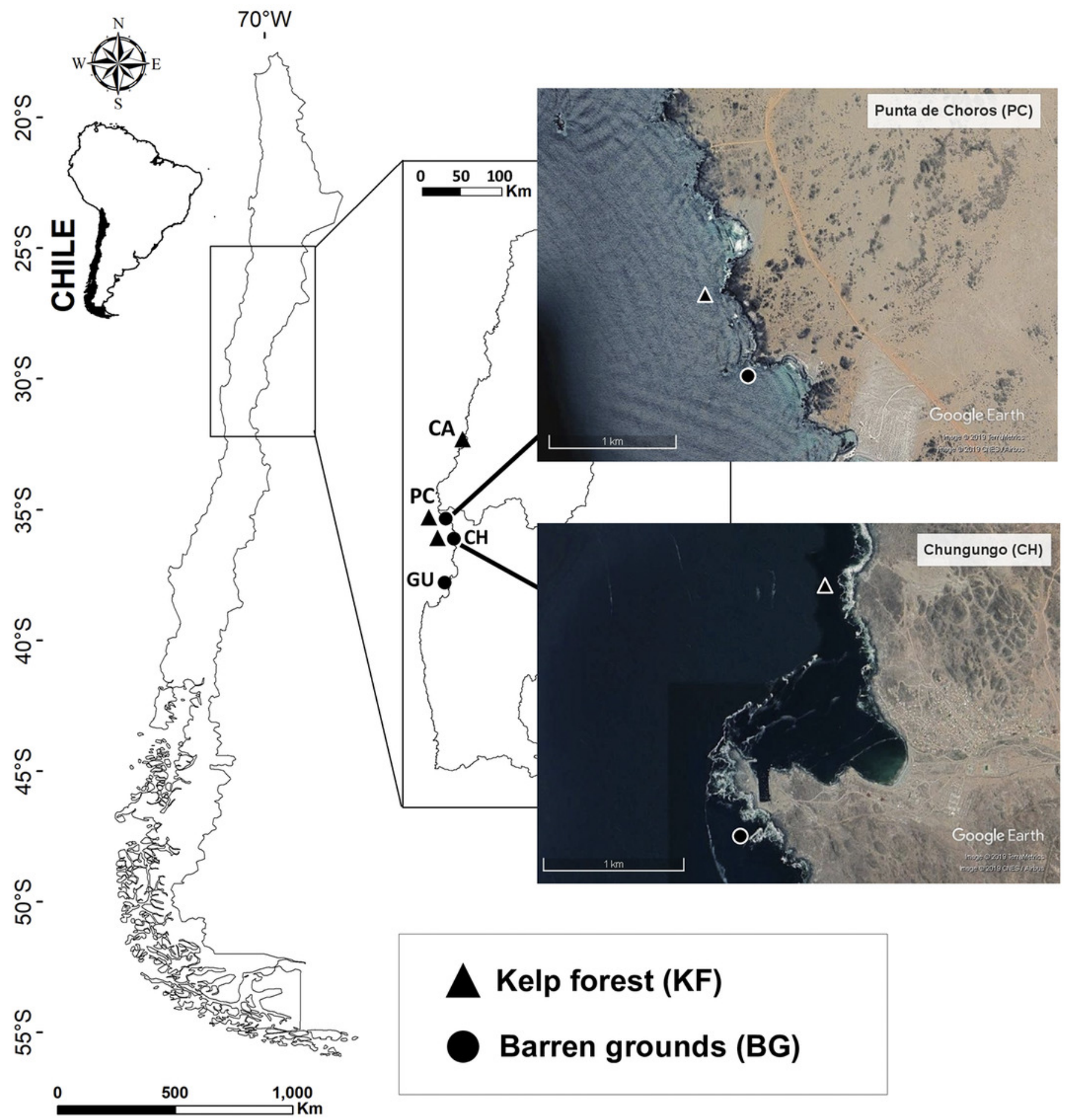


Figure 2

Structures used to record communities, to carry out predation assays and to document predation events.

(A) Metal frame structure to generate vertical view, (B) Metal arm structure to generate horizontal view, (C) vertical view perpendicular to the bottom, and (D) horizontal view parallel to the bottom. Square structures on the base of the structures were eternity fibre cement plates of $40 \times 40 \mathrm{~cm}$. Photo Credits: Nicolás Riquelme-Pérez. 

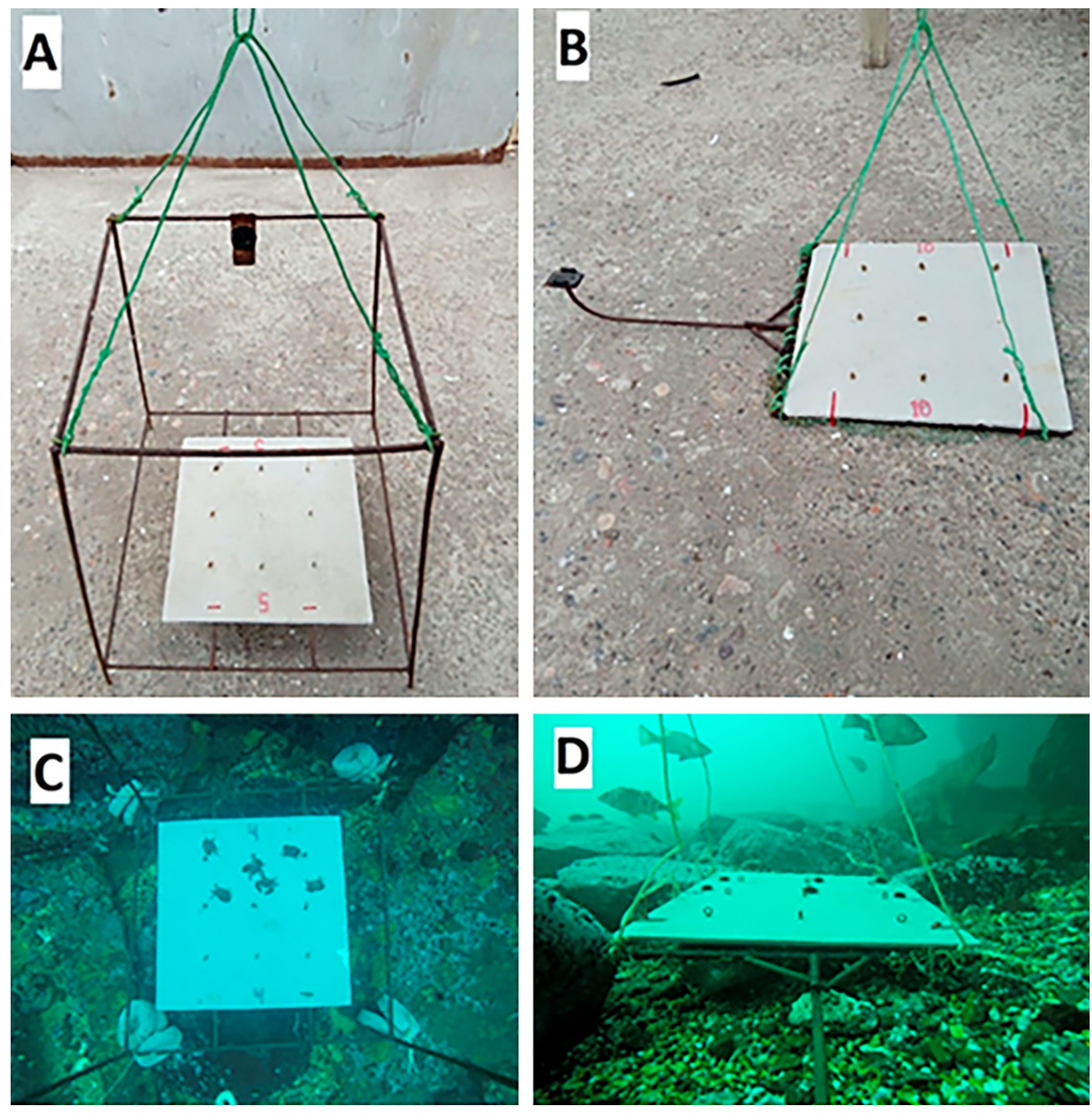
Figure 3

Species of fish observed in videos by location and habitat $(\mathrm{KF}=$ Kelp forest, $\mathrm{BG}=$ Barren grounds), black fish shapes show presence.

Fish species richness is the number of fish species observed the respective location and habitat. *Species observed outside the 40 min standardized video duration for quantitative evaluation.

\begin{tabular}{|c|c|c|c|c|c|c|}
\hline & CA & \multicolumn{2}{|c|}{ PC } & \multicolumn{2}{|c|}{$\mathrm{CH}$} & GU \\
\hline Species & $\mathrm{KF}$ & $\mathrm{KF}$ & BG & $\mathrm{KF}$ & BG & BG \\
\hline Scartichthys viridis/gigas & & & & D & P & $D$ \\
\hline Pinguipes chilensis & & & & & & 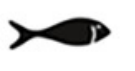 \\
\hline Cheilodactylus variegatus & & & & & & \\
\hline Aplodactylus punctatus & & & & & & \\
\hline Chromis crusma & & & & & & D \\
\hline Labrisomus philippii & & & & & & \\
\hline Hemilutjanus macrophthalmos & & & & & > & \\
\hline Graus nigra & & & & 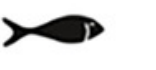 & & \\
\hline Paralabrax humeralis & & & & & & \\
\hline Semicossyphus danvini & & & & & & \\
\hline Acanthistius pictus & & & & & & \\
\hline Total fish species richness: & 9 & 5 & 6 & 5 & 6 & 4 \\
\hline Number of videos (Vertical/Horizontal): & $7 / 5$ & 9/9 & $6 / 8$ & $5 / 6$ & $8 / 6$ & $6 / 6$ \\
\hline
\end{tabular}


Figure 4

Fish species richness (SR, number of species video ${ }^{-1}$ ) by study site, observed in videos with (a) vertical, and (b) horizontal view.

Only the first 80 frames were considered, each frame was scanned every 30 sec during the first $40 \mathrm{~min}$ of the video. The box plots present first and third quartile, while the bold lines in the boxes show the medians of SR. Vertical lines are the minimum and maximum values (1.5*IQR, interquartile range); dots show jittered raw data points and dots outside the range are outliers.

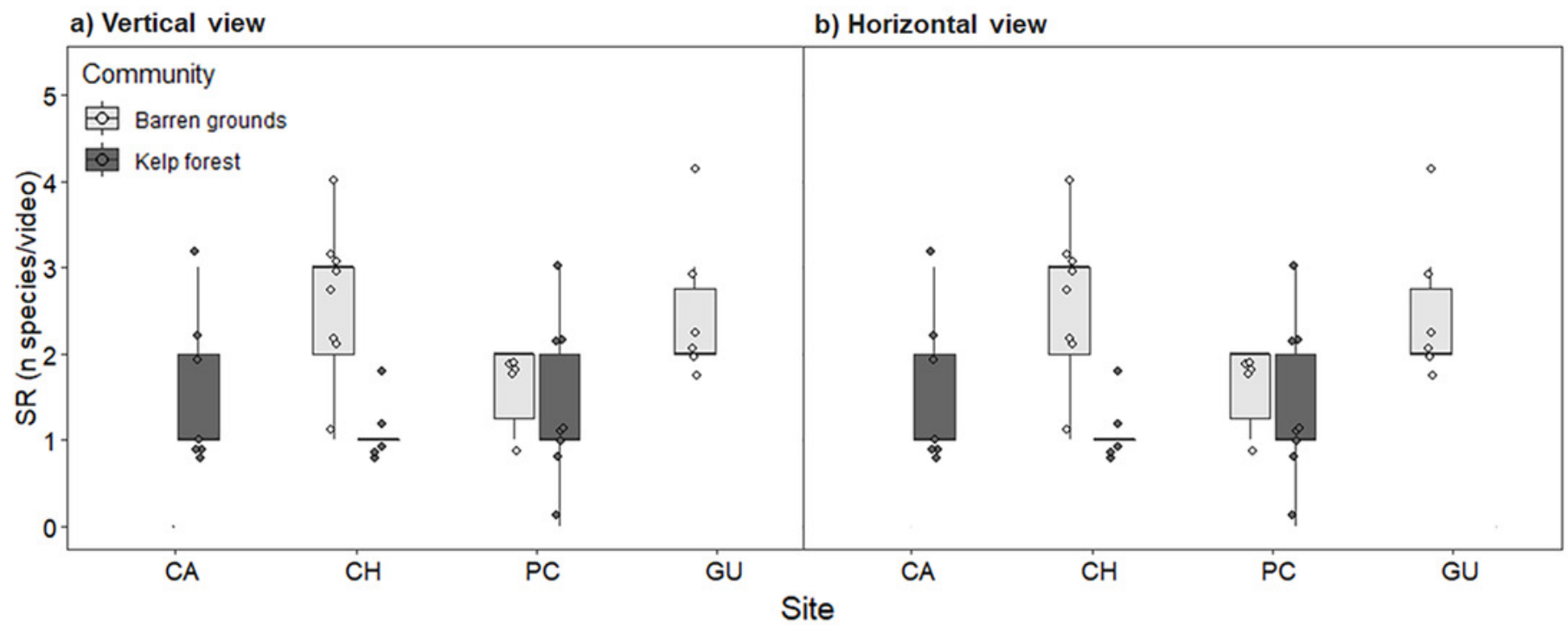




\section{Figure 5}

Frequency of occurrence (\%) (FO) of the three most common predatory fish species by study site in videos with (a) vertical, and (b) horizontal view.

FO was percentage of frames in which at least one individual of each species was observed (of a total of 80 frames that were scanned every $30 \mathrm{sec}$ during the first 40 min of the video). The box plots present first and third quartile, while the bold lines in the boxes show the medians of FO; vertical lines are the minimum and maximum values (1.5*IQR or the interquartile range); dots show jittered raw data points and dots outside the range are outliers; dots with a number above them (which correspond to a FO value), represent outliers outside the $y$-axis scale. 
a) Vertical view

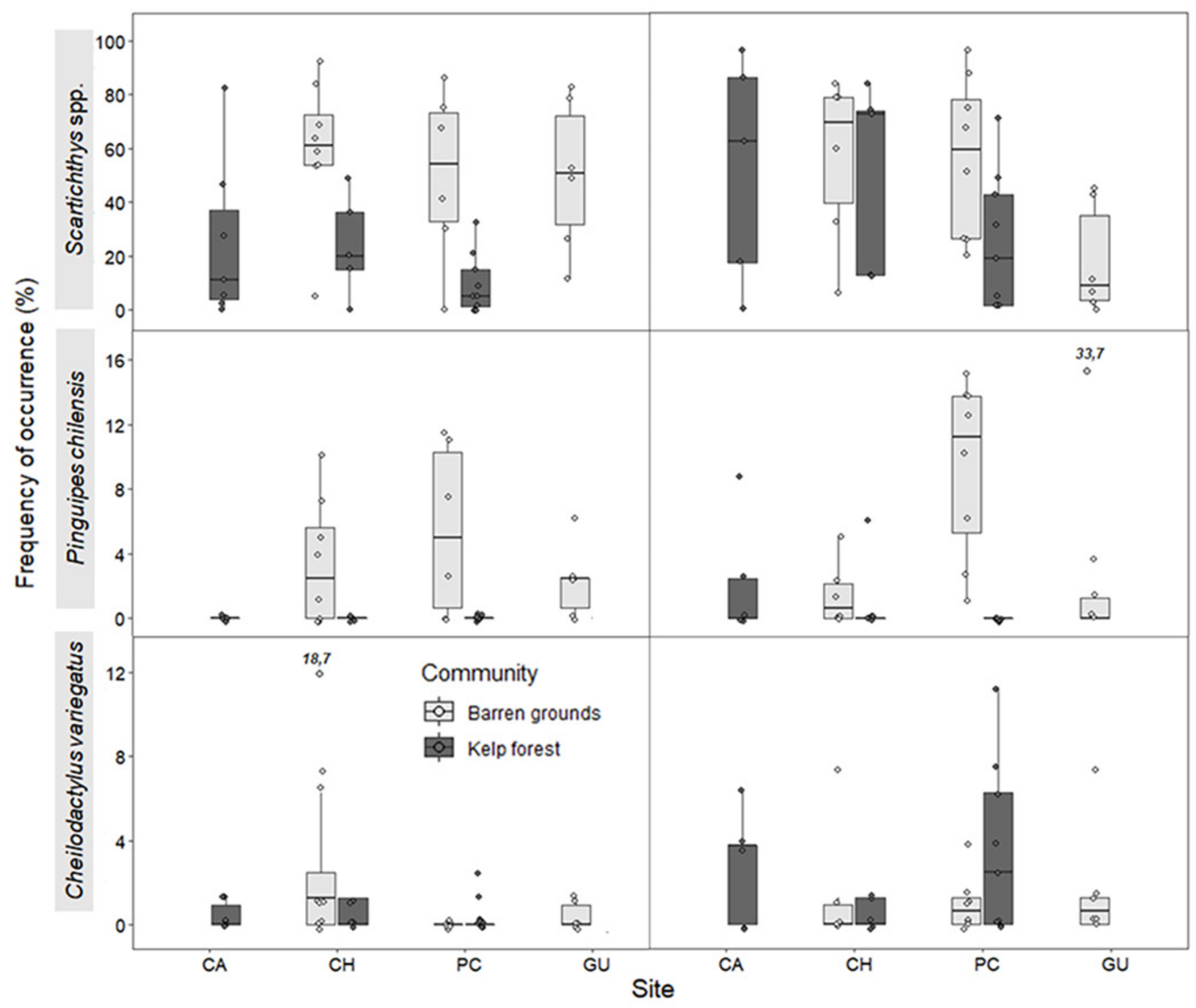




\section{Figure 6}

Maximum abundance (MaxN) of the three most common predatory fish species by study site in videos with (a) vertical, and (b) horizontal view.

MaxN indicates the maximum abundance of any species observed in one of the 80 frames that were surveyed every $30 \mathrm{sec}$ during the first $40 \mathrm{~min}$ of the video recordings. The box plots present first and third quartile, while the bold lines in the boxes show the medians of MaxN; vertical lines are the minimum and maximum values $(1.5 * \mathrm{IQR}$ or the interquartile range); dots show jittered raw data points and dots outside the range are outliers; dots with a number above them (which correspond to a MaxN value) represent outliers outside the $y$-axis scale. 
a) Vertical view

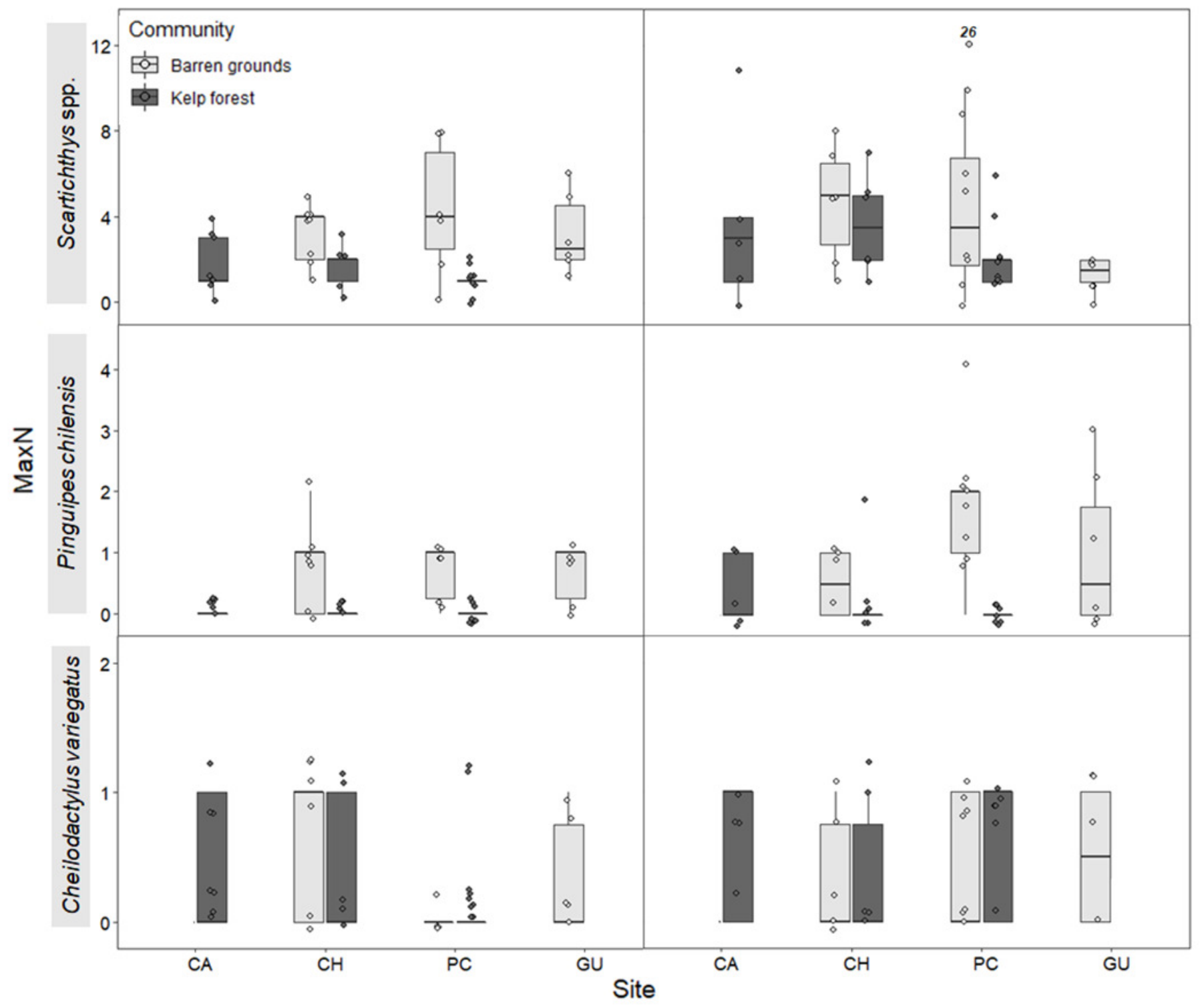




\section{Figure 7}

Percentage of (a) T. niger (sea urchin), and (b) P. laevigatus (crab) consumed at each study site.

The box plots present first and third quartile, while the bold lines in the boxes show the medians of consumption (\%); vertical lines are the minimum and maximum values (1.5*IQR or the interquartile range); dots show jittered raw data points and dots outside the range are outliers. 


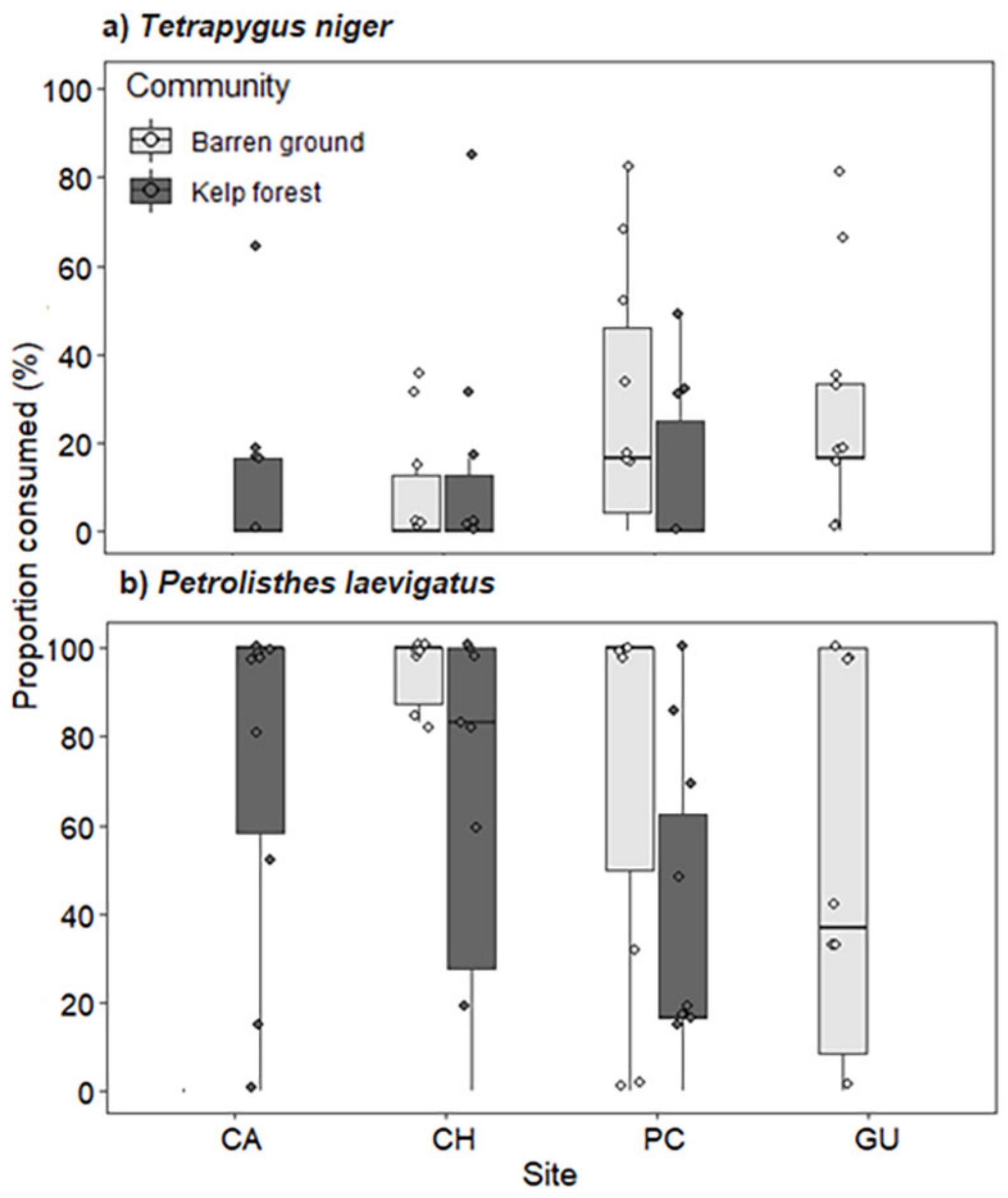

